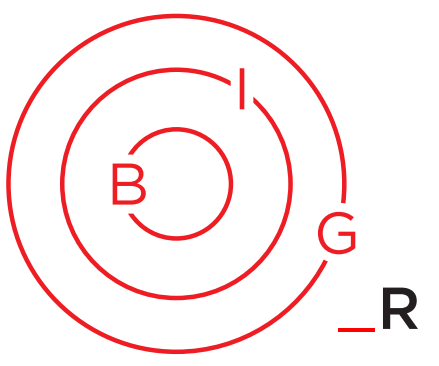

ARTICLE
Borders in Globalization Review

Volume 1, Issue 1 (Fall 2019): 66-82

https://doi.org/10.18357/bigr11201919259

Lance Hadley *

\begin{abstract}
Contemporary spatial research on civil conflict in Sub-Saharan Africa has largely focused on border regions as spaces of limited political and economic opportunity. These studies largely adopt approaches that present borderlands as institutionally desolate regions lacking in governance, economic opportunity and political inclusion and giving rise to the feasibility of rebel conflict. While spatial analyses focus on territorially-based capabilities, such as state power projection, they typically overlook borderlands and their territorial distinctiveness with regards to rebel capabilities. This paper specifically explores the structural effects of borders on rebel capabilities and argues that Sub-Saharan Africa's porous borders enhance the capabilities of rebels to operate in nearby territories. I empirically test this hypothesis with a zero-inflated negative binomial model and spatially disaggregated conflict events data from the Armed Conflict Location \& Event Data Project dataset mapped to the PRIO-GRID 0.5-degree $x$ 0.5-degree geographic data structure. In total, the analysis covers 14,120 georeferenced rebel conflict events in 37 countries between 1997-2019. The results provide strong evidence that territories nearer to borders are likely to experience more battle events relative to other territories, suggesting that borderlands may enable distinct conflict-related capabilities for rebels not found elsewhere. Additionally, the model also differentiates the effects that the border may have on conflict, testing the effect of rough terrain, resources, excluded groups, and towns at the border. Of the variables tested, the results suggest that territories with border towns significantly increase the capabilities of rebels to engage in conflict and suggest a more nuanced scholarly consideration of cross-border institutions that facilitate rebel conflict.
\end{abstract}

\title{
Introduction
}

The spatially disaggregated nature of civil conflict in Sub-Saharan Africa (SSA) has traditionally been a confounding aspect for scholars of conflict analysis. More so than other regions, conceptualizing the SSA state as a container of homogenously distributed sovereignty has typically yielded limited explanatory value for empirical analyses related to civil conflict. Necessarily, many scholars have turned to disaggregated geographic approaches to study the territorially-bound structural conditions that enable rebels to engage in conflict with the state. Similarly, the data tools available to researchers are updating too. New geocoded datasets and geographic infor- mation system (GIS) technologies are giving conflict scholars more sophisticated techniques to unpack spatial processes and more precisely identify the conditions that make armed conflict feasible in SSA.

At the same time, borderlands analyses have proliferated in recent decades and converged on a distinct thematic approach to multi-disciplinary research (Newman 2006a; Paasi 2011). Borderlands analyses have challenged concepts of traditional sovereignty creation at the juridical border, the nexus of sovereignty and territoriality beyond the border, and the state monopoly on sovereignty

\footnotetext{
* Lance Hadley is a PhD Candidate at the Norman Paterson School of International Affairs, Carleton University, Canada. Contact: Lance.hadley@carleton.ca
} 
construction (e.g. Andersen et al. 2018; CôtéBoucher et al. 2014; Parker and Vaughan-Williams 2009). Especially in the African context, post-coIonial approaches to the study of borders have yielded fertile discussion and insights for how social behaviour can be understood in practice relative to colonial border legacies (e.g. Flynn 2008; Mbembé and Rendall 2000; Nugent and Asiwaju 1996). Yet, despite the analytical dynamism in conflict research and territorial discourses in borderlands research, few scholars have attempted to cross-pollinate the two disciplines. This paper attempts that task in two ways: first by highlighting discrete gaps in the current direction of spatially disaggregated conflict analysis which stand to benefit from a borderlands approach; and second, by presenting an empirical analysis of spatial conflict inspired by a focus on borderlands' institutional structures.

The article proceeds as follows: first, it highlights previous scholarly engagement with conflict and borders, with specific attention to the underlying center-periphery assumptions of contemporary conflict analyses. The second section shifts the focus of analysis to the rebel behaviours in SSA's borderlands that exploit the border as an institution to enhance their capabilities to contest the state. This section also presents testable hypotheses, situated in a borderlands approach to conflict research. The third section outlines the framework and data for empirical analysis. The fourth section presents the model and results. This paper ultimately concludes with a discussion of the findings and potential future contributions for interdisciplinary scholars to develop this paper's experimental objective of bridging borderlands and conflict research.

\subsection{Center-Periphery Grievance Assumptions in Disaggregated Conflict Analyses}

Perhaps no other research program has been as broadly influential to the field of conflict analysis as the greed and grievance agenda. In its first rendition, Collier and Hoeffler (2004) quantitatively explored the economic theory that "atypically severe grievances, such as high inequality, a lack of political rights, or ethnic and religious divisions in society" motivated rebels to engage in armed conflict. The authors later iterated the study to suggest a more precise feasibility model; that "where rebellion is feasible it will occur, motivation is indeterminate, or itself endogenous to the opportunities thereby opened for illegal income" (Collier et al 2009, p.24). As it relates to this paper, I argue that the conceptual developments and operationalization of state power in Africa in political science and conflict literatures has limited the integration of borderlands as a meaningful area of focus. Further, border regions superficially appear to fit this narrative as politically and economically desolate places absent of the state apparatus. While the feasibility model presents an opportunity to introduce borderland institutions to conflict analysis, limited engagement between the two literatures has resulted in a paradoxical interpretation for border regions in contemporary conflict analysis - that border regions represent both aggrieved spaces suffering from the retreat of the state and, at the same time, sites of state-control that delimit domestic and international territory.

In contemporary conflict analysis literature, a central factor that makes rebellion more feasible, and therefore more likely, is the concept of state capacity. The basic logic is that, where a state can credibly exercise a monopoly of violence (or sovereignty) conflict is unlikely to occur. Conversely, where a state lacks the capacity to enforce its sovereignty and can rationally be challenged, conflict will occur. More so, a state's projection of sovereignty and power is well-recognized in the conflict literature as a distinctly territorial process (e.g. Vasquez 1995; Jackson 1990; see Diehl 1991 for a review). In the context of the modern African state, political science scholars have highlighted the asymmetry between state boundaries and territorial sovereignty, and point to the emergence of the post-colonial state as the legitimate international actor and participant in the international legal regime, regardless of the state's capacity to exercise absolute territorial control (Ayissi 2009; Englebert 2002; Herbst 2000; Jackson and Rosberg 1982). Given this reality, state territoriality itself is suggested as a dynamic process within SSA states by which governance is a negotiated process with other governance institutions - not de facto a national government process.

Scholars have typically described this dynamic territoriality process by pointing to the African state's governance retreat from international boundaries; that historical legacies of mercantile extraction left an inheritance of core-periphery relationships within the then newly independent states. Indeed, authors have pointed to Africa's strained political and economic histories, which deprioritized borderland governance in favour of a governable core (Herbst 2000). Authors point to the emergence of neo-patrimonial governance and appropriated extractive institutions, which prioritize regions of wealth creation and redirect local resources and loyalties towards those groups that direct state power (Acemoglu and Robinson 2012; Lindemann 2008). International forces too, have played their part in the erosion of the state at the periphery, as African states prioritize the most important areas of export trade - typically the capital (Boone 2007; Mkandawire 2001; Konadu-Agyemang 2000). Further, the periphery by its nature as geographically distant from the core, limits state intervention. Within this political configuration, the geographic 
Borders in Globalization Review | Volume 1 | Issue 1 | Fall 2019

Hadley, "Borders and the Feasibility of Rebel Conflict"

periphery is seemingly restricted from national economic policy and often from political inclusion.

While not intending to dispute the principle that a state's power is territorially projected from the core (and certainly not the findings associated with the strength of the variable), a binary conceptualization of territory that is integrated into state governance - or not - restricts meaningful analysis of alternative institutions outside the sovereign control of the state. Further, core-periphery concepts in the context of African state retreat embeds narrative tropes of the African border as the lawless 'frontier' and integrates assumptions of borderlands as regions of political emptiness; where the border zone represents a 'not-yet-civilized' region awaiting penetration from the political center (Korf and Raeymaekers 2013).

The binary conceptualization of state institutions carries over into quantitative conflict analyses too, where scholars typically include "distance to capital," to control for the relative territorial capacity of the state (e.g. Rugerri et al. 2016; Buhaug 2010; Rustad et al. 2006). Proxying power projection from the core site of state power, regions closer to the capital are considered more "governable" and less accessible regions relative to the capital (typically border regions) are considered more difficult to effectively govern. More to the point however, methodologies for spatial conflict analysis typically embed core-periphery concepts in the methodological unit of analysis.

A growing pool of disaggregated analyses exclusively analyse conflict events to determine their ex-post conditions - after the event has occurred and been recorded. Given that conflict events can only manifest if rebels or the state have an opponent to fight, analyses will necessarily be restricted to dichotomous illustrations of the battle zone as a contest between state-controlled or rebel-controlled. This implies that all other areas are either uncontested state or rebel territories. In short, by focusing exclusively on where conflict occurs, and not where it doesn't, these analyses tautologically operate within the dichotomy of state core / anarchic periphery, leaving little room for analysis of territorial institutions outside of the state's capacity for making war.

An additional barrier to the study of African borderlands in conflict analyses is that rational-legal approaches to international boundaries position borders as the state's defensive, ostensibly inviolable, line against anarchic external forces (Zureik and Salter 2013; Bigo 2006; Ackleson 2003; Agnew and Crobridge 2002; Andreas 2003; Wilson and Donnan 1998). As a politico-legal technology of the state, international borders in this literature are conceptualized as the legal line that simultaneously separates and joins state's sovereign territories. Territorial institutions along this boundary line are explicitly state-sanctioned processes (or not) that selectively deny territorial access to cross-border forces, be it migratory, economic, or military.

One strand of civil conflict analysis has explored a similar interpretation of borders as defensive walls, which when weakened, permit clandestine activity across the border. Here, inter-state proximity, contiguity, or border length is said to provide more opportunities, or connection points, of inter-state sanctioned conflict (e.g Starr 2002; Gleditsch et al. 2006; Starr and Thomas 2002, 2005). In the state's absence from the border, borderlands are presented as spaces of violence and perpetual conflict, again requiring state protection. Granted, these analyses are typically focused at the state level, and are less concerned with the subnational distribution of civil conflict, yet, similar assumptions are still employed in spatially disaggregated studies. Dummy binary variables are typically included for a conflict event's neighbourhood contiguity with a nearby border. The issue is that, an arbitrary proximity dummy for all borders, paints these regions with the same rational-legal inspired brush and may ignore the realities of border institutions with gradated or differential effects on rebel conflict feasibility.

Indeed, the critique of international borders as features of separation and the embedded assumptions of a homogenously powerful territorial state is not new in borderlands literature (see Reid-Henry 2010; Newman 2006b; Agnew 1994). Instead, borderlands scholars have embraced borders as spaces where "diverse patterns of trans-boundary interaction may take place, ranging from confrontation and exclusion to cooperation, integration and inclusion" (Newman 2008, 127; Sohn 2014; Blake 2000; Nugent and Asiwaju 1996). Additionally, scholars have embraced the state retreat narrative as an opportunity to specifically explore international borders as key sites of regulatory institutions.

These alternative regulatory institutions can include cross-border structures that bind peoples based on ethnic or religious affinities, market incentives, or family and other migratory factors. A vibrant institution that is especially common throughout the SSA region is informal (as well as formal) cross-border trade (The World Bank 2011; Lesser and MoisLeeman 2009; Muzvidziwa 2005; Peberdy 2000). Cross-border markets have traditionally prospered from traders' exploitation of market differentials on either side of the border and provide a strong counterexample to borders as desolate spaces (Hashim and Meagher 1999). Analysis of the market destinations of cross-border traders at the Busia crossing on the Kenyan and Ugandan border, for 
example, reveals an extensive cross-border trade network that fans widely across each country, connected through the border market (Hadley and Rowlatt 2019) - illustrated by Figure 1. Along West Africa's ubiquitous international boundaries, border markets have developed into distinct institutional hubs for the cross-border circulation of people and goods (Walther 2011). Niang (2013) examines the activity of one of these markets located at the intersection of the Guinea-Guinea Bissau-Senegal border; suggesting that the absence of Senegalese border monitoring has allowed for the market exchanging "over 1,000 tons of products worth about 250 million CFA francs (US $\$ 450,000$ )" (44). Scholars have also suggested that the strength of cross-border trade networks in SSA, in contrast to "bumbling" state initiatives towards integration, may represent a more productive driver of economic integration (Nshimbi and Moyo 2017; Meagher 2003, 2001). Perhaps tellingly, several SSA countries have also explicitly integrated the development of cross-border market infrastructure into their regional economic trade strategies (Koroma et al. 2017; Egg and Igue 1993; Igue 1992; e.g. Ministry of Trade and Industry - Rwanda 2013; Southern African Development Community 2010).

In addition to cross-border market incentives, the capacity of borders to enforce spaces of the 'us' and the 'other' is heterogenous throughout SSA. Indeed, colonial bordering of SSA territory (which largely persists to the present-day) seldom reflected the realities of SSA's communities and physical geographic features (Griffiths 2005; Nugent and Asiwaju 1996). While certainly not the case with all colonial administrations, Söderbaum (2016) describes that French colonies also promoted a considerable degree of horizontal integration between colonies and thereby limiting the separating features of international boundaries. Relative to the present-day, Griffiths (2005) explains how the border often plays a limited role in hampering the cross-border ethnic networks that straddle the border;

little attention is paid to the boundary in the course of their everyday lives. People regularly cross the border, marry spouses and reside across the border for long periods. They attend all manner of ceremonies, social occasions and family celebrations... These activities do not normally concern governments and... are seldom hampered (83).

Additionally, Griffiths points to the common state practice in SSA to place customs posts several kilometers behind the international border so as not to disrupt innocent cross-border activities. Further, he concludes that the length of international borders and the distribution of ethno-linguistic groups, such as the Hutu's and Tutsi's, are too complex for "any simple, simplistic, linear divide." In West Africa, Adepoju (2005) posits that border deregulation has been a select strategy of West African states with economies too small to absorb their citizens to allow labour migrants to easily transit to the popular West African economy of the day. As a result, ethnic support networks have developed on both sides of the border.

So far, discussion has highlighted the seemingly marginalized role of border regions in conflict analysis literature. In one strand of the literature, the distribution of conflict in border regions represent areas from which the state has retreated, giving way to non-state territory and institutions for conflict. In another strand, conflict in border

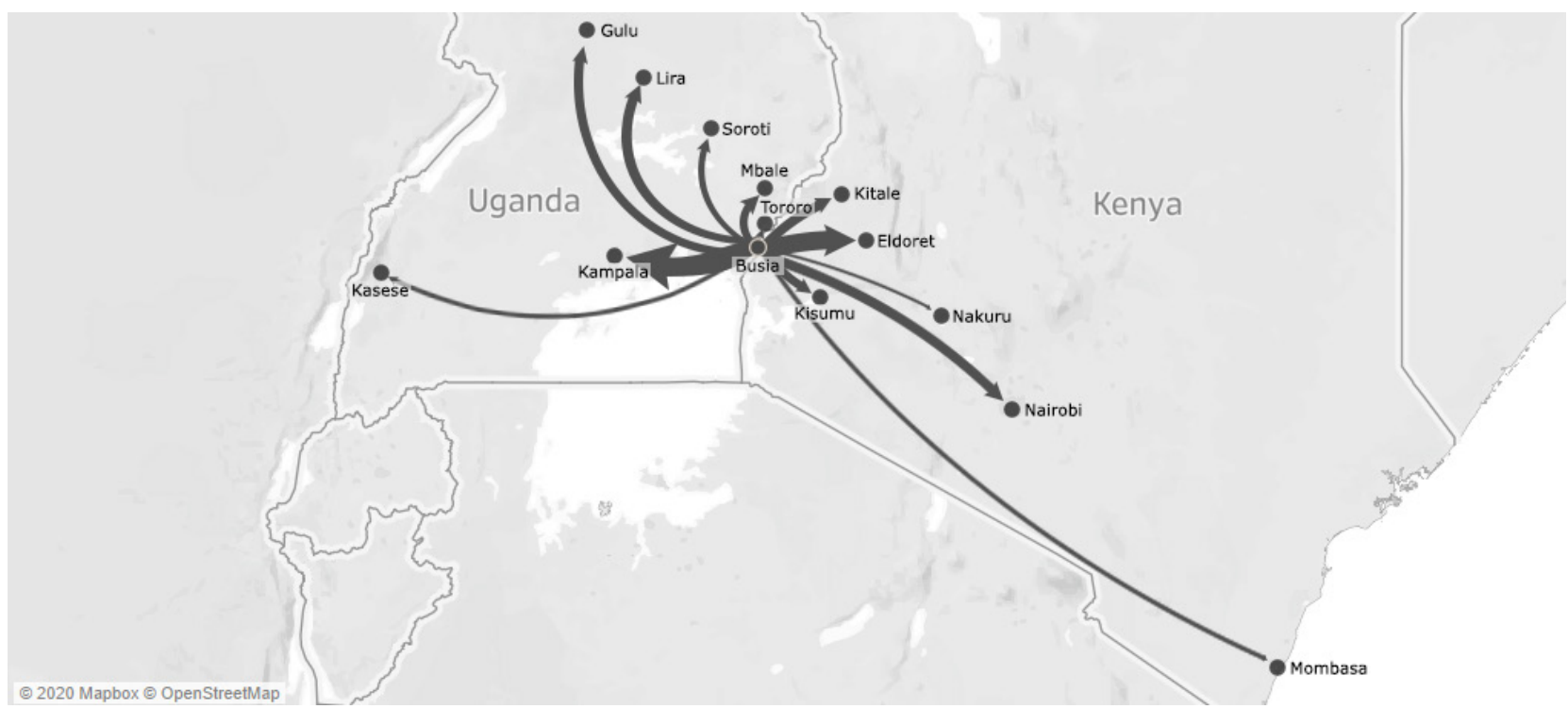

Figure 1. Market networks through Busia border crossing on the Uganda/Kenya border. Produced with data from Hadley and Rowlatt (2019). 
Borders in Globalization Review | Volume 1 | Issue 1 | Fall 2019

Hadley, "Borders and the Feasibility of Rebel Conflict"

regions represents the failure of the state to enforce the non-permeability of the border, which has been violated by violent external forces. In both cases, the role of alternative institutions in making conflict feasible is overlooked. Briefly, examples have been provided with the aim to challenge these conceptualizations of the border as desolate and anarchic spaces between states. Instead, complex institutional interactions are present, despite the absence of the state. It is in highlighting the role of these institutions that distinct borderlands approaches stand to benefit the study of conflict. The next section constructs theoretical hypotheses related to the role of borderlands on rebel capability with a more precise operationalization of territorial border processes throughout Africa.

\subsection{Sub-Saharan Africa's Borders and Rebel Capability}

Perhaps the most clearly relevant effect of borders on rebel capability is the proximity to unregulated, unmonitored foreign territory. While the border may indicate the de jure boundary of national sovereignty, rebel operational theatres are not bound by the same international norms. I frame my analysis to suggest that borderlands represent territorial resources that are exploited by rebel groups to gain access to unregulated cross-border networks. Support from these networks may take various forms. Most directly related to the conduct of rebel conflict is the transfer of easily transportable small arms across poorly controlled borders. Schroeder and Lamb (2006) describe that,

UN experts investigating arms embargo violations in Somalia documented the delivery of arms to Somali militias by Ethiopian truck convoys. Similarly, Liberia's Charles Taylor transported many of the weapons he provided to the RUF across the border in trucks. Rogue soldiers, rebels, refugees and others also walk across borders with one or two small arms at a time (71).

Alusala (2010) describes how panya routes, or informal footpaths across borders, are in most instances "of no concern to border security officials and hence remain unmanned" (18). In East Africa, these routes form common smuggling routes for the transfer of illicit resources. He adds that "Even if it were possible, it would take enormous time and long queues to search all those bicycles and mamas carrying sacks of potatoes and grains for their own consumption" (22). As such, unregulated borders provide few barriers for the inflow of personnel and materials necessary for armed insurgency.

Supporting resources available to rebels from across the border may also be available in other ways. Scholars have demonstrated that ethnic kin in neighbouring states often played an important role in mobilizing and financing insurgencies (Gleditch 2007; Saideman 2002, 1997; Davis and Moore 1997). To use the language of the conflict analysis literature, international borders permit opportunities for horizontal escalation of conflict, or the transnationalization of conflict. Specifically, the outflow of information to ethnic kin across the border can be designed to produce processes of social polarization that galvanize support for the aggrieved borderland community. Authors also find demonstration effects that link generates ethnic support across borders (Weidmann 2015; Forsberg 2008; Kuran 1987). Across the border, in unregulated extra-territorial space, political entrepreneurs may take the opportunity to communicate the grievances and social realities in the home-country. Outside of the juridical control of the state, governments are often unable to present a falsification to exclusionary claims made cross-border political entrepreneurs. In this way, transnational ethnic support can be drummed up in support of rebel conflict. Harff and Gurr's work (1998) describes this support among external groups in their: typologies of 'accelerators' that escalate ethno-political conflict and genocides (emphasis added):

1. Formation of coalitions among regime opponents;

2. Clashes between regime supporters and communal groups;

3. Increase in external support for communal groups;

4. Empty threats of external involvement against the government.

By way of example, Carment and Schnabel (2004) identify small-scale localized killings in Rwanda, Burundi, and DRC as prefiguring the later genocide. The 1990s saw these conflicts slowly horizontally escalate as ethnic groups increasingly supported ethnic violence until ethnic conflicts became fused together "into a much larger, more violent network of closely interlinked conflicts" (35).

Further, supporting ethnic groups across the border can provide quantitatively more and qualitative different resources than those directly available to the aggrieved ethnic group (Lidow 2016; Salehyan 2008; Collier and Hoeffler 2004). The difficulty of a government to monitor and limit the logistical support of rebellions in countries outside its own territory makes locating bases and safe havens just across the border an advantageous strategy for perpetuating conflict. In effect, while a seemingly negligent distance for local ethnic communities, for a state, the other side of the border has a distance of its own. What's more is that negotiating international political or military cooperation with the neighbouring country is often required for effective military counteraction to rebel hit-and-run tactics. ${ }^{1}$ 
Lastly, international borders permit access to unregulated transnational economic networks. Here, the 'lootable resources' thesis of the conflict literature is applied (Le Billon 2014; Buhaug et al. 2009; Humphreys 2005; Collier and Hoeffler 2004). The mineral-rich DRC has received special attention in this regard. Researchers have identified the use of cross-border 'military commercialism' in the DRC whereby a bordering state deployed its military in support of an actor in exchange for access to profits (Turner 2007; Klare 2001; Dietrich 2000). Nearly all outside parties operating in the Second Congo War engaged in military commercialist support of border communities, strategically driven by targets of economic plunder. Rwanda and Uganda specifically engaged the North East region to gain access to agricultural products, minerals, forest products, livestock and cash. Similarly, Angola supported DRC government forces in exchange for oil products and Zimbabwean support was purchased in exchange for access to timber profits. In other regions, Collier adds "diamonds funded the National Union for the Total Independence of Angola (UNITA) rebel group during Angola's long civil war, as well as the Revolutionary United Front (RUF) in Sierra Leone" (Collier 2009). Common to these examples, border porousness is exploited by smugglers to transport illicit resources outside the regulatory space of the state. Subsequently, profits (such as small arms discussed earlier) can be smuggled back as a resource for border communities. As such, the international border represents a significant logistical resource for evading state and accessing the economic networks of illicit profit.

Access to the types of 'in' and 'out-flows' described above is hypothesized to provide additional strategic capacity for rebel actors to engage in conflict - whether against the state, civilians, or others. These resources have the potential to substantially affect the feasibility of rebel conflict and enhance rebel's capabilities to conduct operations closer to the regime's home base than would otherwise be possible. Still, just as with most strategic resources, farther distances from the border are also likely to increase supply lines from cross-border resources, introducing increased transport costs, risks of government interdiction, and limiting strategic responsiveness. In this way, it is expected that rebels will cluster nearer to borders, at once supported by the resources on the other side, and at the same time potentially restricted from extending territorial control farther inland.

H1: Territories closer to international borders are likely to experience more rebel conflict relative to other national territories

Based on the discussion above, I also include several related hypotheses to identify border territories that are more likely to facilitate rebel capabilities relative to other territories. Firstly, cross-border markets and border towns have been described as sites of vibrant cross-border activity. While little literature has described any potential effect of border towns on the capabilities of rebels, I suggest that the cross-border institutions that facilitate market dynamics may also facilitate the material resources required by rebels.

H2: Towns at the border are likely to experience more rebel conflict relative to other territories in the same country

Rough terrain has been described by conflict scholars as more difficult to police and can provide a source of refuge for rebels (Rustad et al. 2006; Buhaug and Rød 2006). I extend this theory to suggest that government regulation of movement in rough terrain is limited, permitting easier access to out-of-country resources, which can be exploited by rebels for increased fighting capacities.

H3: Border territories with rough terrain are more likely to experience more rebel conflict relative to other territories in the same country

Access to transnational ethnic networks beyond the border has been described above as potentially increasing rebel's ability to engage in conflict. I suggest that groups that are discriminated or excluded from the national government, who are nearer to borders, have better access to support networks to facilitate potential armed conflict.

H4: Border territories that contain excluded groups are more likely to experience more rebel conflict relative to other territories in the same country

Lastly, lootable resources has been described above as being a significant driver of conflict, by virtue of their ease of transport. Easily extractable resources at the border, then, provide opportunities for not just immediate plunder, but by virtue of their proximity to networks beyond the border, also provide opportunities to illicitly traffic resources out of the country to unregulated international markets.

H5: Border territories with lootable resources are more likely to experience more rebel conflict relative to other territories in the same country

This section has described an argument that international borders represent logistical channels for accessing additional support networks for rebels to conduct armed conflict. The hypotheses, constructed in this way, embed significant principles related to borderlands analyses. First, I position borders at the center of my study by focusing on the projection of rebel capacity sourced from, or 
Borders in Globalization Review | Volume 1 | Issue 1 | Fall 2019

Hadley, "Borders and the Feasibility of Rebel Conflict"

across, the other side of the border - rather than on the projection of the state from the capital. Second, I present a non-dichotomous hypothesis of borders' influence on rebels. This integrates the concept that state territory may express multiple or competing sovereignties. Thirdly, I disaggregate the length of the border to consider differentiated effects of the border on rebel capability. The next section outlines the data structure, the data, and the statistical method to operationalize and test these hypotheses.

\subsection{Data and Method}

This study employs several geographic information system (GIS) techniques to approximate the territorial influences on rebel capabilities. To facilitate this analysis, this paper relies on the PRIO-GRID's data framework, which divides terrestrial areas into $0.5 \times 0.5$-degrees gridded cells. Depending on the position of the globe, these grid cells represent approximately 55 square kms (the approximation is taken at the equator. The area varies due to the change of the widths between longitudinal lines). Using a temporally and territorially fixed gridded data structure presents an opportunity to employ a unit of analysis that is largely insensitive to exogenous political influences, boundaries and developments.

I exclude grid cells in SSA countries that are not territorially contiguous with other countries from this analysis. These countries are Cape Verde, Comoros, Madagascar, Mauritius, Seychelles, São Tomé \& Príncipe. Given that the main theorized effect of borders in this study is the increased landbased capability to access in and out flows through neighbouring countries, territories with international borders that abut international seas, large lakes, or large rivers are also excluded from this study.

Additionally, the focus of this project is principally on territorially structural factors that affect rebel capability. As a result, the data for this analysis is intended to proxy structural, not dynamic, processes. While structural data are useful for understanding the root causes, enabling conditions, and background factors associated with territorial conflict, structural data poorly explains poorly explains specific events or patterns related to conflictual human social interaction. Additionally, structural data cannot specifically account for variations in the scope, severity, and timing of such patterns. It is not the intention of this study to explain individual dynamic conflict events, but to explore the long-term structural conditions that affect the dependent variable. As such, the selection and framing of data proceeds in such a way to identify slow-moving structural variables, transform dynamic data into structurally representative data, and limit analysis to methodologically appropriate regions in SSA.

In lieu of a disaggregated structural variable of rebel capability, this analysis constructs its dependent variable from ex-post counts of battles that have occurred within each of the framework's grid cell. The basic logic is that, for grid cells where many rebel battles have occurred, those cells have structural attributes that facilitate a higher propensity for recurring rebel conflict. To construct this count variable, data is sourced from the Armed Conflict Location \& Event Data Project (ACLED), which records georeferenced violent conflict events in SSA from 1997 to the current day (Raleigh et al 2010). The time period used for this analysis is from January 1st 1997 to August 1st 2019. Additionally, I use ACLED's definition of battles, which are defined as "a violent interaction between two politically organized armed groups at a particular time and location" and battles are included even if there are no fatalities from the event. Additionally, ACLED battle events are coded with interaction codes associated with the two main actors of an event. The focus of this paper is on rebels' capabilities at the border and, as such, I use battle events with interactions where at least one of the two actors are a rebel group. This includes the following interactions: rebels vs military; sole rebel action; rebels versus rebels; rebels versus political militia; rebels versus communal militia; rebels versus rioters; rebels versus protestors; rebels versus civilians; and rebels versus others. To be sure, the ACLED dataset uses a definition of rebels that is consistent with this paper's hypotheses: rebels are political organizations that engage in violent acts as the primary means to pursue political goals. ${ }^{2}$ Each grid cell is coded with the total count of rebels' battles occurring within that cell during the time period as the dependant variable.

One such limitation to this approach is the assumption that capital cities, borders, and national authority are static spatial variables. The secession of South Sudan poses a significant challenge in this regard; where the distances to the national border in grid cells located in the South of the Sudan changed significantly in 2011. Somalia also poses a challenge to this territorial analysis due to the dynamic governing capacities of autonomous regions such as Somaliland, Jubaland, and Mogadishu in recent years. For example, where variables based on the distance to capital are intended to proxy concepts of gradated sovereignty, the distance to Mogadishu may be confounded by the complexities of shared sovereignty in the region, given the significant role of semi-autonomous organs in the country. Recognizing that these regions present a unique opportunity for territorial analyses that can more accurately accommodate the shifting dynamics in these regions, this study 


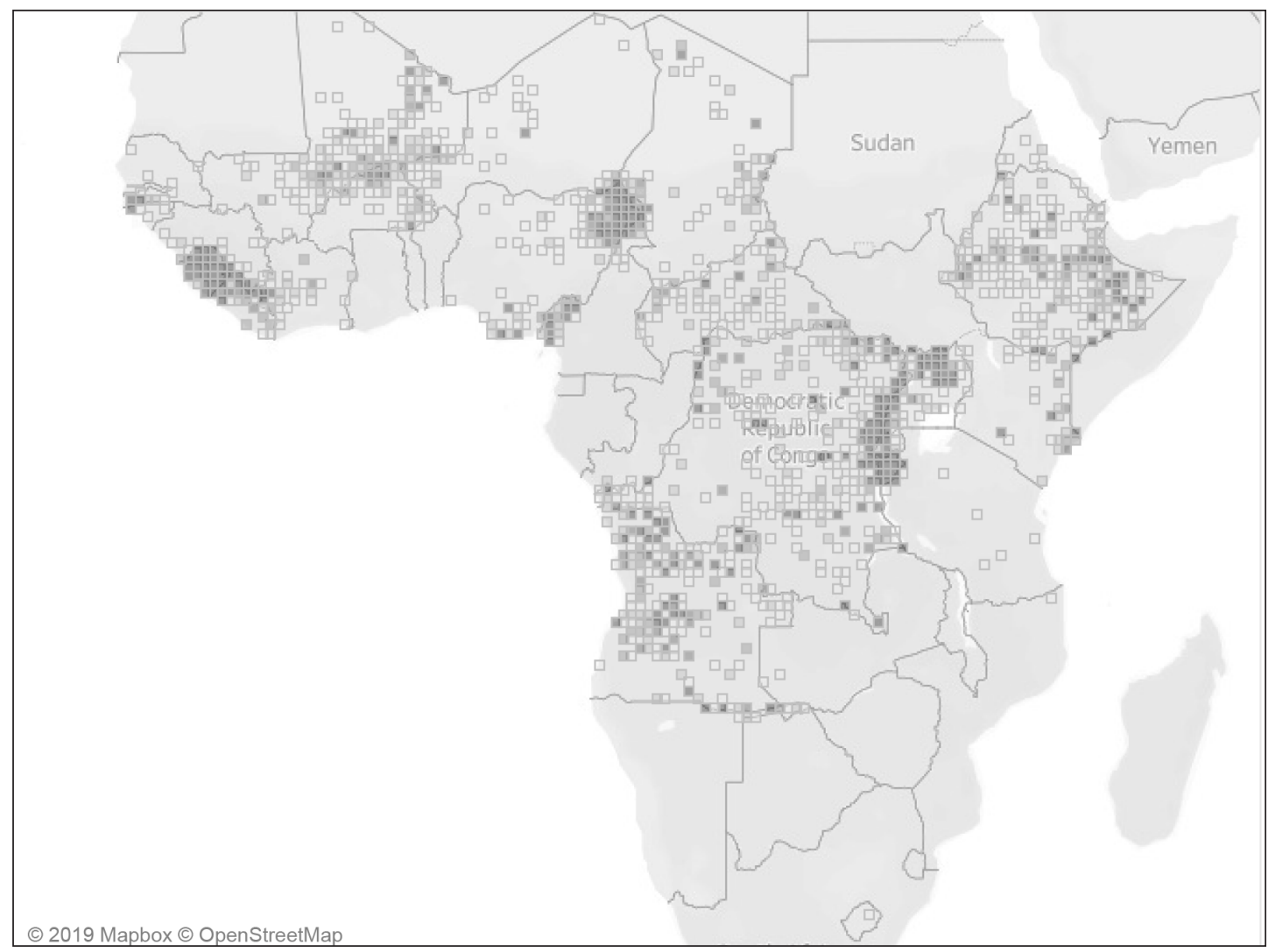

Figure 2. Rebel conflict counts in the dataset.

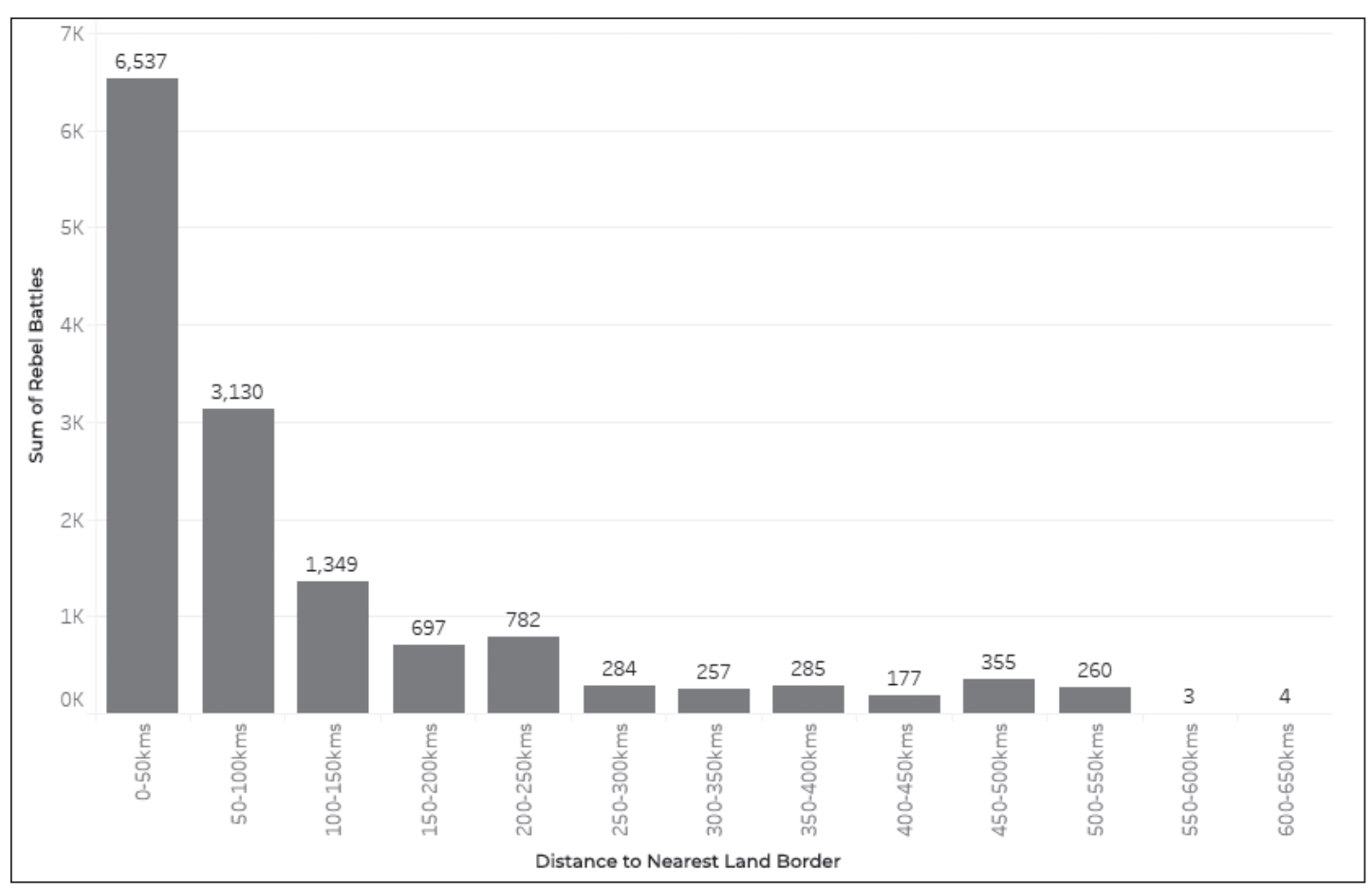

Figure 3. Sum of rebel battle events, by distance to border. 
Borders in Globalization Review | Volume 1 | Issue 1 | Fall 2019

Hadley, "Borders and the Feasibility of Rebel Conflict"

excludes Sudan, South Sudan, and Somalia from the larger structural analysis.

There are some regional challenges to territorially-based empirical analyses of conflict in SSA. Apart from Angola, rebel battle counts in other Southern African countries during this time period exhibit limited territorial variation; 69 battle events over the approximately 22-year time period. While these countries are included in the territorial analyses and limited variation is considered in selecting an appropriate statistical method, their exclusion is tested in robustness tests. While also tempting to include North Africa in the data sample, the geography of the region presents significant analytical challenges that are beyond the scope of this study. Specifically, while the de jure border may be up to $500 \mathrm{kms}$ South from the capital, the Sahara Desert's prohibitive effect on travel may have confounding barrier effects or opportunities for rebel or national capabilities, which would be more appropriately analyzed in a separate study.

The last limitation is due to the spatial resolution of this study's gridded framework and has particular relevance to The Gambia and eSwatini (formerly Swaziland). With each grid cell representing territory approximately $50 \mathrm{~km} \times 50 \mathrm{~km}$ and given the countries' relatively small land area it is likely that these countries' national influence on it's corresponding territories will not be accurately isolated by the grid cell. The grid cells containing Gambian and eSwatini territory is therefore excluded.

Altogether, this approach yields 14,120 rebel battle events in 6,414 grid cells across 37 SSA countries. The rebel battles count distribution is visualized in Figure 2 and Figure 3 gives the total rebel battle events relative to the distance to the nearest land border.

\section{Description of Data}

This paper has so far theorized a positive effect of borders and rebel capabilities. Empirically, it is expected that border distance and rebel conflict count is negative; that rebels farther from the border must travel greater distances to access the in and out flow capabilities provided by the border. To capture the potential effect of borders on proximate territory, a cell's centroid distance to the nearest land-contiguous neighboring country is included as a model variable. This distance measurement is based on country border data using cShapes v.0.4 data (Weidmann et al 2010). To be sure, interpreting specific rebel capabilities from a distance variable is challenging. To address this, additional dummy variables are included for cells that include a border to test for correlations of specific hypothesized rebel capabilities afforded by the border.
Border Towns: Grid cells with border towns are identified as those that have towns with a population of at least 50,000 inhabitants. Data is drawn from the PRIO-GRID's aggregation of Uchida et al.'s (2010) data, which is the result of network analysis using a combination of several sources, most collected between 1990 and 2005 .

Border Mountains: Border grid cells with mountainous terrain are identified based on the UNEP's Mountain Watch Report (Blyth et al 2002). The dataset provides a high-resolution mountain raster which identifies mountainous terrain based on elevation, slope and local elevation range. Border cells where at least $25 \%$ of the grid cell is considered mountainous are identified as border mountain cells.

Border Forest: Border grid cells are with forests are identified based on the ISAM-HYDE historical landuse dataset (Meiyappan et al. 2012). Similar to the process to identify border mountains, the dataset provides a high-resolution raster of land classification. Border cells where at least $25 \%$ of the grid cell is considered forested are identified as border forest cells.

Border Excluded Groups: Border grid cells with excluded groups are identified based on the GeoEPR Dataset 2018 (Vogt et al. 2015). The dataset identifies the status and location of politically relevant ethnic groups settled in the grid cell. If a group, whose territory overlaps with the gridded cell, has been excluded or discriminated against for more than ten years since 1997 (the beginning of the rebel count data timeframe), that cell is given a positive binary value.

Border Resources: Border grid cells with easily extractable resources such as placer gold, alluvial diamonds, and other gems are identified from an aggregation of several georeferenced datasets; from Gilmore et al (2005), the GOLDDATA v1.2 dataset (Balestri 2012), and the GEMDATA dataset (Lujala 2009). Cells in which any valuable resources are found, are given a positive binary value.

I also include several control variables. Spatial spillover and contagion have been described by conflict scholars as a driver of conflict events in contiguous territory, whereby conflict in one territory influences conflict in another (Buhaug et al. 2008; Ward and Gleditsch 2002; Murdoch and Sandler 2002). A variable for the sum of rebel conflict counts in the eight queen-contiguous territories relative to the grid cell is added to control for this spatial effect. Distance to capital has been described by Buhaug and Rød (2006) scholars as relevant to the relative location of conflict, as contestations of state governance is more likely in territories that are nearer to the capital city. Thus, a variable 


\begin{tabular}{llllll} 
Variable & Obs & Mean & Std. Dev. & Min & Max \\
\hline Rebel Battle Count & 6,414 & 2.201434 & 14.73485 & 0 & 629 \\
Nearby Rebel Battles & 6,414 & 17.87948 & 67.79998 & 0 & 1253 \\
Distance to Border & 6,414 & 142.0748 & 119.0727 & 0.003383 & 629.0215 \\
Distance to Capital & 6,414 & 592.7296 & 400.2666 & 3.985501 & 1910.548 \\
Mountainous Terrain & 6,414 & 16.03481 & 27.43058 & 0 & 100 \\
Forested Terrain & 6,414 & 13.61716 & 27.22567 & 0 & 99.89 \\
Nearest Resources & 6,414 & 219.2304 & 240.0826 & 1 & 1291.819 \\
Excluded Ethnic Groups & 6,414 & 0.415497 & 0.492846 & 0 & 1 \\
Population & 6,414 & 131,635 & 328,292 & 0 & $9,179,302$ \\
Border Town & 6,414 & 0.018241 & 0.133834 & 0 & 1 \\
Border Mountains & 6,414 & 0.070783 & 0.256481 & 0 & 1 \\
Border Forest & 6,414 & 0.043187 & 0.203293 & 0 & 1 \\
Border Excluded & 6,414 & 0.111163 & 0.314359 & 0 & 1 \\
Border Resources & 6,414 & 0.025101 & 0.156445 & 0 & 1 \\
Cell Area & 6,414 & 2980.859 & 130.6972 & 2023.274 & 3091.067
\end{tabular}

Table 1. Descriptive Statistics

is added which measured the distance from the capital city to the centroid of the grid cell. Proportions of mountainous and forested terrain within a grid cell are also included as control variables. The effect of resources as a driver of conflict is also included in a distance variable that measures the distance of the grid centroid to the nearest within country valuable resources. Nearby resources are identified with the same aggregation technique as the border resources variable. Excluded ethnic groups are included with the same dataset used to identify excluded groups at the border - if a grid cell contains an ethnic group, it is given a positive dummy variable. Lastly, Grid population is proxied by a variable represented by the logged sum of pixel values (number of persons) within the gridded cell from the Gridded Population of the World v4.11 dataset. GPWv4 data values for each cell are estimated from national censuses spanning from 2005 to 2014.3

Lastly, I include a sampling weight based on the land area of a cell. As the gridded framework is constructed according to a geographic coordinate system, grid cell area can vary at different latitudes. This variation in cell area may quantitatively capture more or less conflict by simply measuring more or less land area. Table 1 summarizes the descriptive statistics for each of these variables.

\section{Statistical Method}

The dependent variable for this study is the cumulative number of rebel conflict events in each grid cell from January 1st 1997 to August 1st 2019. However, this analysis' gridded data structure, which is based on a geographic sampling technique, is likely to present an overdispersion of zero-count rebel conflict observations. Rebel conflict is simply not likely to occur in the majority of grid cells, either due to factors such as extreme remoteness, sparse populations, or data collection limitations. Distinguishing between grid cells with true zeros and excess zeros, therefore necessitates an appropriate statistical method to account for grid cells' expected heterogenous variance and means of conflict counts. Possible statistical models that relax assumptions of observations' independence and unequal variance and means of the dependent variables are the negative binomial regression model, a zero-inflated Poisson model (ZIP), or a zero-inflated negative binomial model (ZINB). I employ a zero-inflated negative binomial model, given the expected excessive zeros and flexibility with overdispersed count outcome variables. A significant likelihood ratio test comparing the two models and a significant z-test in the Vuong test also support selecting a ZINB model for this analysis $(\mathrm{Pr}>=0.0000$ and $\operatorname{Pr}>z=0.0000$ respectively) .4 
Borders in Globalization Review | Volume 1 | Issue 1 | Fall 2019

Hadley, "Borders and the Feasibility of Rebel Conflict"

The ZINB model is a two-step model: first the inflation step employs a logistic regression to predict whether a given observation belongs to a population of true zeroes, which accounts for grid cells that are simply not exposed to rebel conflict. The second step performs a negative binomial probability estimation of rebel conflict counts and includes a parameter which accounts for overdispersion. All distance variables are log transformed in the model. In all models, I cluster the standard errors on the national unit of the grid cell to control for country-specific effects such as country size, government capacity, or infrastructural qualities.

\subsection{Empirical Results}

In Table 2, I report the estimates from the zero-inflated negative binomial regression model estimates for the total count of rebel conflict events in each grid cell. The left side of each model reports the estimates corresponding to the negative binomial part of the model. These estimates are to be interpreted as the increase in log number of events associated with a one-unit increase in the explanatory variable. The right side of the model column reports the "inflate" part of the model, or the extent to which there are more zeroes in the data than implied by the negative binomial distribution. These estimates are interpreted as an inverse logistic regression model, or the probability of a non-zero event. Conversely, a negative estimate in the inflate equation means that an increase in the explanatory variable increases the probability of observing at least one event in that grid cell.

Model 1 reports a base model for this analysis. Models 2 through 6 add a single border variable to

\begin{tabular}{|c|c|c|c|c|c|c|c|c|c|c|c|c|}
\hline \multirow[b]{2}{*}{ Variables } & \multicolumn{2}{|c|}{ Model 1} & \multicolumn{2}{|c|}{ Model 2} & \multicolumn{2}{|c|}{ Model 3} & \multicolumn{2}{|c|}{ Model 4} & \multicolumn{2}{|c|}{ Model 5} & \multicolumn{2}{|c|}{ Model 6} \\
\hline & $\begin{array}{c}\text { Count } \\
\text { Equation }\end{array}$ & $\begin{array}{c}\text { Inflate } \\
\text { Equation }\end{array}$ & $\begin{array}{c}\text { Count } \\
\text { Equation }\end{array}$ & $\begin{array}{c}\text { Inflate } \\
\text { Equation }\end{array}$ & $\begin{array}{c}\text { Count } \\
\text { Equation }\end{array}$ & $\begin{array}{c}\text { Inflate } \\
\text { Equation }\end{array}$ & $\begin{array}{c}\text { Count } \\
\text { Equation }\end{array}$ & $\begin{array}{c}\text { Inflate } \\
\text { Equation }\end{array}$ & $\begin{array}{c}\text { Count } \\
\text { Equation }\end{array}$ & $\begin{array}{c}\text { Inflate } \\
\text { Equation }\end{array}$ & $\begin{array}{c}\text { Count } \\
\text { Equation }\end{array}$ & $\begin{array}{c}\text { Inflate } \\
\text { Equation }\end{array}$ \\
\hline $\begin{array}{l}\text { Distance to } \\
\text { Border }\end{array}$ & $\begin{array}{c}-0.098^{* * *} \\
(-3.061)\end{array}$ & $\begin{array}{c}0.013 \\
(0.193)\end{array}$ & $\begin{array}{l}-0.066^{*} \\
(-1.845)\end{array}$ & $\begin{array}{c}0.014 \\
(0.189)\end{array}$ & $\begin{array}{c}-0.085^{* * *} \\
(-2.707)\end{array}$ & $\begin{array}{l}0.079 \\
(1.152)\end{array}$ & $\begin{array}{c}-0.103^{* * *} \\
(-2.799)\end{array}$ & $\begin{array}{c}-0.005 \\
(-0.065)\end{array}$ & $\begin{array}{c}-0.143^{* * *} \\
(-3.143)\end{array}$ & $\begin{array}{c}0.017 \\
(0.248)\end{array}$ & $\begin{array}{c}-0.105^{* * *} \\
(-3.139)\end{array}$ & $\begin{array}{c}0.012 \\
(0.166)\end{array}$ \\
\hline $\begin{array}{l}\text { Distance to } \\
\text { Capital }\end{array}$ & $\begin{array}{l}0.149^{*} \\
(1.708)\end{array}$ & $\begin{array}{l}-0.033 \\
(-0.198)\end{array}$ & $\begin{array}{l}0.174^{* *} \\
(2.169)\end{array}$ & $\begin{array}{c}-0.017 \\
(-0.103)\end{array}$ & $\begin{array}{l}0.152^{*} \\
(1.848)\end{array}$ & $\begin{array}{c}-0.032 \\
(-0.205)\end{array}$ & $\begin{array}{l}0.150^{*} \\
(1.715)\end{array}$ & $\begin{array}{c}-0.038 \\
(-0.226)\end{array}$ & $\begin{array}{l}0.150^{*} \\
(1.784)\end{array}$ & $\begin{array}{l}-0.033 \\
(-0.198)\end{array}$ & $\begin{array}{c}0.144 \\
(1.613)\end{array}$ & $\begin{array}{l}-0.037 \\
(-0.221)\end{array}$ \\
\hline $\begin{array}{l}\text { Nearby } \\
\text { Battles }\end{array}$ & $\begin{array}{l}0.504^{* * *} \\
(9.909)\end{array}$ & $\begin{array}{c}-1.085^{* * *} \\
(-5.177)\end{array}$ & $\begin{array}{l}0.501^{* * *} \\
(9.949)\end{array}$ & $\begin{array}{c}-1.077^{* * *} \\
(-5.243)\end{array}$ & $\begin{array}{l}0.498^{* * *} \\
(9.604)\end{array}$ & $\begin{array}{l}-1.061^{* * *} \\
(-6.015)\end{array}$ & $\begin{array}{l}0.505^{* * *} \\
(9.766)\end{array}$ & $\begin{array}{l}-1.074^{* * *} \\
(-5.305)\end{array}$ & $\begin{array}{c}0.499 * * * \\
(9.785)\end{array}$ & $\begin{array}{c}-1.083^{* * *} \\
(-5.231)\end{array}$ & $\begin{array}{c}0.504^{* * *} \\
(9.937)\end{array}$ & $\begin{array}{l}-1.083^{* * *} \\
(-4.964)\end{array}$ \\
\hline $\begin{array}{l}\text { Mountainous } \\
\text { Terrain }\end{array}$ & $\begin{array}{c}0.001 \\
(0.343)\end{array}$ & $\begin{array}{c}0.004 \\
(0.749)\end{array}$ & $\begin{array}{l}0.000 \\
(0.113)\end{array}$ & $\begin{array}{c}0.004 \\
(0.657)\end{array}$ & $\begin{array}{l}0.000 \\
(0.016)\end{array}$ & $\begin{array}{l}-0.000 \\
(-0.014)\end{array}$ & $\begin{array}{c}0.001 \\
(0.342)\end{array}$ & $\begin{array}{c}0.004 \\
(0.737)\end{array}$ & $\begin{array}{c}0.001 \\
(0.305)\end{array}$ & $\begin{array}{c}0.004 \\
(0.729)\end{array}$ & $\begin{array}{c}0.001 \\
(0.316)\end{array}$ & $\begin{array}{l}0.004 \\
(0.731)\end{array}$ \\
\hline $\begin{array}{l}\text { Forested } \\
\text { Terrain }\end{array}$ & $\begin{array}{c}0.000 \\
(0.064)\end{array}$ & $\begin{array}{l}-0.006 \\
(-0.619)\end{array}$ & $\begin{array}{c}-0.000 \\
(-0.023)\end{array}$ & $\begin{array}{l}-0.006 \\
(-0.635)\end{array}$ & $\begin{array}{c}0.000 \\
(0.054)\end{array}$ & $\begin{array}{c}-0.006 \\
(-0.634)\end{array}$ & $\begin{array}{c}0.001 \\
(0.169)\end{array}$ & $\begin{array}{c}-0.004 \\
(-0.486)\end{array}$ & $\begin{array}{c}0.001 \\
(0.281)\end{array}$ & $\begin{array}{c}-0.006 \\
(-0.607)\end{array}$ & $\begin{array}{l}0.000 \\
(0.122)\end{array}$ & $\begin{array}{c}-0.006 \\
(-0.590)\end{array}$ \\
\hline $\begin{array}{l}\text { Nearest } \\
\text { Resources }\end{array}$ & $\begin{array}{l}-0.048 \\
(-0.757)\end{array}$ & $\begin{array}{l}-0.075 \\
(-1.421)\end{array}$ & $\begin{array}{l}-0.046 \\
(-0.728)\end{array}$ & $\begin{array}{l}-0.074 \\
(-1.407)\end{array}$ & $\begin{array}{l}-0.048 \\
(-0.771)\end{array}$ & $\begin{array}{l}-0.075 \\
(-1.450)\end{array}$ & $\begin{array}{l}-0.049 \\
(-0.767)\end{array}$ & $\begin{array}{l}-0.078 \\
(-1.482)\end{array}$ & $\begin{array}{c}-0.051 \\
(-0.803)\end{array}$ & $\begin{array}{l}-0.077 \\
(-1.455)\end{array}$ & $\begin{array}{l}-0.054 \\
(-0.752)\end{array}$ & $\begin{array}{l}-0.075 \\
(-1.181)\end{array}$ \\
\hline $\begin{array}{l}\text { Excluded } \\
\text { Groups }\end{array}$ & $\begin{array}{l}0.262^{*} \\
(1.666)\end{array}$ & $\begin{array}{c}-0.238 \\
(-0.567)\end{array}$ & $\begin{array}{c}0.250 \\
(1.592)\end{array}$ & $\begin{array}{l}-0.241 \\
(-0.575)\end{array}$ & $\begin{array}{l}\text { O.259* } \\
(1.645)\end{array}$ & $\begin{array}{c}-0.228 \\
(-0.550)\end{array}$ & $\begin{array}{c}0.270 \\
(1.604)\end{array}$ & $\begin{array}{c}-0.215 \\
(-0.505)\end{array}$ & $\begin{array}{l}\text { O.386* } \\
(1.949)\end{array}$ & $\begin{array}{c}-0.232 \\
(-0.545)\end{array}$ & $\begin{array}{c}0.274 \\
(1.624)\end{array}$ & $\begin{array}{c}-0.230 \\
(-0.540)\end{array}$ \\
\hline Population & $\begin{array}{l}0.144^{* * *} \\
(3.645)\end{array}$ & $\begin{array}{l}-0.162^{* * *} \\
(-2.590)\end{array}$ & $\begin{array}{l}0.138 * * * \\
(3.351)\end{array}$ & $\begin{array}{l}-0.160^{* *} \\
(-2.551)\end{array}$ & $\begin{array}{l}0.146 * * * \\
(3.996)\end{array}$ & $\begin{array}{l}-0.157^{* * *} \\
(-2.670)\end{array}$ & $\begin{array}{l}0.145^{* * *} \\
(3.648)\end{array}$ & $\begin{array}{c}-0.163^{* * *} \\
(-2.591)\end{array}$ & $\begin{array}{l}0.147^{* * *} \\
(3.714)\end{array}$ & $\begin{array}{l}-0.161 * * * \\
(-2.581)\end{array}$ & $\begin{array}{l}0.145^{* * *} \\
(3.641)\end{array}$ & $\begin{array}{l}-0.162^{* *} \\
(-2.555)\end{array}$ \\
\hline $\begin{array}{l}\text { Border } \\
\text { Town }\end{array}$ & & & $\begin{array}{l}0.634^{*} \\
(1.958)\end{array}$ & $\begin{array}{c}-0.252 \\
(-0.424)\end{array}$ & & & & & & & & \\
\hline $\begin{array}{l}\text { Border } \\
\text { Mountains }\end{array}$ & & & & & $\begin{array}{c}0.210 \\
(0.689)\end{array}$ & $\begin{array}{l}1.049^{* *} \\
(2.318)\end{array}$ & & & & & & \\
\hline $\begin{array}{l}\text { Border } \\
\text { Forest }\end{array}$ & & & & & & & $\begin{array}{c}-0.080 \\
(-0.290)\end{array}$ & $\begin{array}{c}-0.358 \\
(-0.933)\end{array}$ & & & & \\
\hline $\begin{array}{l}\text { Border } \\
\text { Excluded }\end{array}$ & & & & & & & & & $\begin{array}{l}-0.345 \\
(-1.222)\end{array}$ & $\begin{array}{c}0.034 \\
(0.095)\end{array}$ & & \\
\hline $\begin{array}{l}\text { Border } \\
\text { Resources }\end{array}$ & & & & & & & & & & & $\begin{array}{l}-0.230 \\
(-0.467)\end{array}$ & $\begin{array}{l}0.009 \\
(0.017)\end{array}$ \\
\hline Constant & $\begin{array}{c}-2.069^{* * *} \\
(-2.610)\end{array}$ & $\begin{array}{c}4.073^{* * *} \\
(2.762)\end{array}$ & $\begin{array}{c}-2.294^{* * *} \\
(0.680)\end{array}$ & $\begin{array}{l}2.705^{* *} \\
(1.234)\end{array}$ & $\begin{array}{l}-2.112^{* * *} \\
(0.648)\end{array}$ & $\begin{array}{l}2.535^{* *} \\
(1.146)\end{array}$ & $\begin{array}{l}-1.998^{* *} \\
(0.786)\end{array}$ & $\begin{array}{l}2.924^{* *} \\
(1.245)\end{array}$ & $\begin{array}{l}-1.858^{* *} \\
(0.805)\end{array}$ & $\begin{array}{l}2.811^{* *} \\
(1.247)\end{array}$ & $\begin{array}{c}-1.923^{* *} \\
(0.821)\end{array}$ & $\begin{array}{l}2.834^{* *} \\
(1.341)\end{array}$ \\
\hline Inalpha & $\begin{array}{l}1.15 \\
(5 .\end{array}$ & $\begin{array}{l}3^{* * *} \\
\text { b13) }\end{array}$ & $\begin{array}{l}1.14 \\
(4.9\end{array}$ & $\begin{array}{l}\text { O*** } \\
\text { O०) }\end{array}$ & $\begin{array}{l}1.12 \\
(5.2\end{array}$ & $\begin{array}{l}4^{* * *} \\
48)\end{array}$ & & $\begin{array}{l}4^{* * * *} \\
28)\end{array}$ & $\begin{array}{l}1.14 \\
(4.9\end{array}$ & $\begin{array}{l}6^{* * *} \\
994)\end{array}$ & $\begin{array}{l}1.15 \\
(4 .\end{array}$ & 383) \\
\hline Observations & & 414 & 6, & 114 & 6, & & & 414 & 6 & 414 & & 414 \\
\hline $\begin{array}{l}\text { Nonzero } \\
\text { observations }\end{array}$ & & 213 & 1,2 & 213 & 1,2 & & & 213 & 1,2 & 213 & & 213 \\
\hline Prob > chi2 & 0.0 & 000 & 0.0 & Do० & 0.0 & 000 & 0.0 & 000 & 0.0 & 000 & 0.0 & 0०० \\
\hline
\end{tabular}

Table 2. Rebel Battles Estimation Results. Note: Robust z-statistics in parentheses (clustered by country), ${ }^{*} p<0.10,{ }^{* *} p<0.05,{ }^{* * *} p<0.01$. 


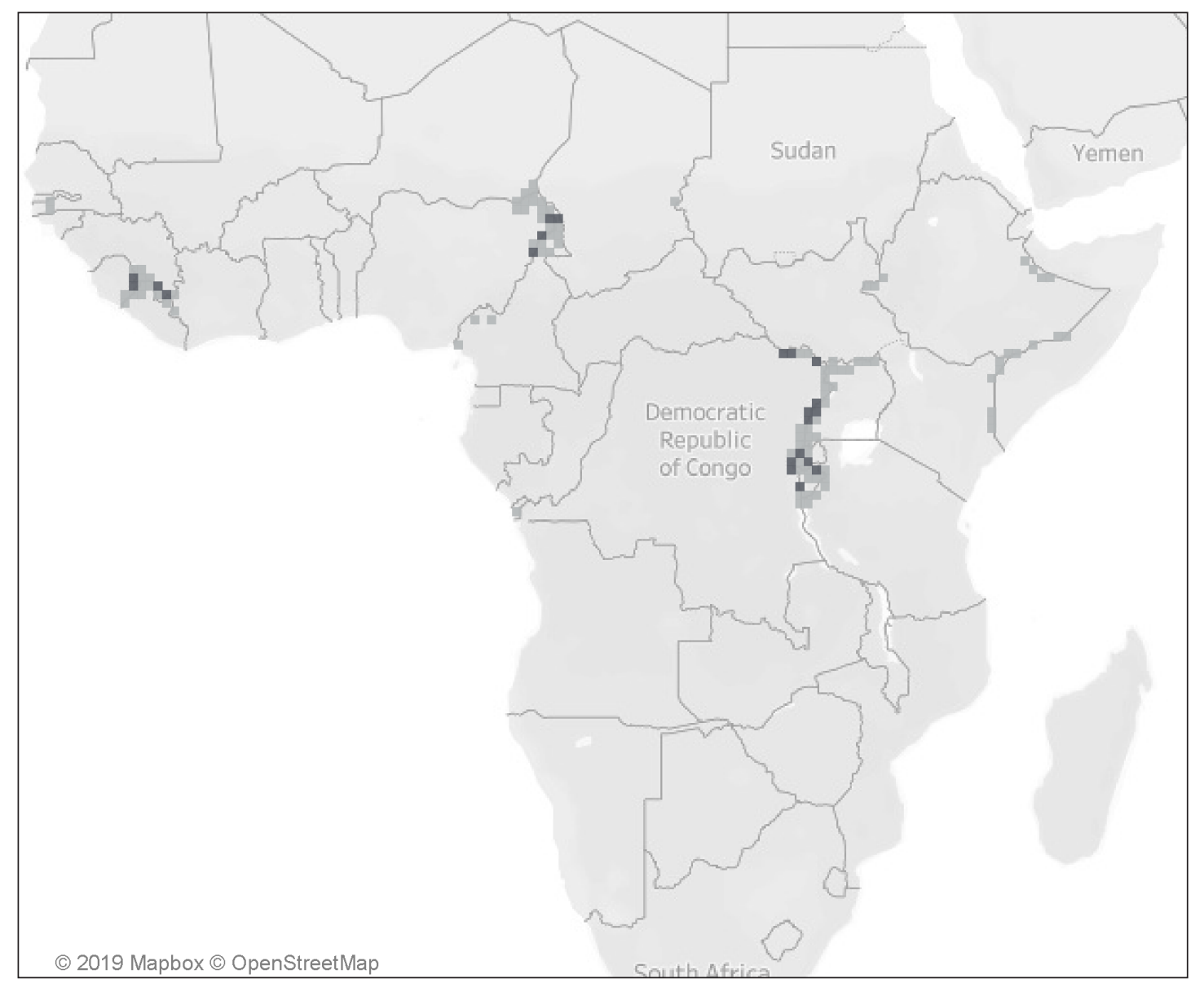

Figure 4. Border hazards identified by the model estimations' results. Border towns identified by darker color.

the specification to test for support of this study's hypotheses. I restrict discussion of the inflate equations simply due to ambiguity of the estimations' relevance to the causal hypotheses of this paper. ${ }^{5}$ In all but one model (model 2 - Border Towns), the coefficient on distance to border is clearly significant at the 99\% level and lends overall support to the central hypothesis that territories closer to international borders are likely to experience more rebel conflict relative to territories farther away from borders. Considering the base model (model 1), the coefficient on the predictor suggests that, on average, for every percentage increase in a territory's distance to border, rebel conflict counts decrease by $9.8 \%$ compared to other territories in the same country, holding all other parameters constant.

Model 2 adds border towns to the base model to test the effect of border towns, and their unique cross-border institutions on rebel capabilities. The significance and sign of the coefficient on the border town variable suggests some support for this theory. The estimation suggests that compared to other non-similar territories in the same country, border towns will experience more rebel conflicts by $63.4 \%$, holding all other parameters constant. It is also important to note, that the level of significance fell on the distance to border variable when the border towns variable was added to the base model. Comparing the two models, this supports the notion that there is a distinct effect on rebel conflict capabilities from institutions that are present in border towns, rather than in territories that are simply near de jure international boundaries.

Model 3 and 4 add dummy variables for mountains and forests that neighbour a border, respectively. The non-significance of the coefficients for these variables does not support the theory that rough terrain at the border significantly increases a rebels' territorial capabilities.

Model 5 adds a dummy variable for excluded groups at the border. The non-significance of the coefficient on the excluded groups variable does not support the theory that borders provide increased access to transnational ethnic networks for the purposes of excluded groups to contest the state. 
Borders in Globalization Review | Volume 1 | Issue 1 | Fall 2019

Hadley, "Borders and the Feasibility of Rebel Conflict"

Lastly, model 6 adds the border resources dummy variable to test the hypothesis that easily lootable resources near the border are more likely to spur conflict as rebels have greater access to illicit outflow channels and unmonitored foreign networks. The non-significance of the coefficient on the border resources variable suggests that border resources do not have a consistently significant relationship, one way or the other, on rebel conflict capabilities.

The control variables with significant coefficients performed largely as expected. The significant and negative sign on the coefficient for distance to capital suggests that the risk of conflict is higher in territories further form the capital, perhaps reflecting the relative strength of the national government across distances. Similarly, the positive spatial influence of nearby conflict is also well supported. Lastly, grid cell population has a positive influence on rebel battle count, perhaps due to the density of potential conflict agents, or high value targets.

A general representation of relative conflict hazards at the border can also be identified from this analysis. An equally weighted product term of neighbouring conflict, distance from the capital, and neighbouring conflict gives a simplified risk factor of territories across SSA most likely to experience more conflict. The territories with a risk factor above the SSA average and within $50 \mathrm{kms}$ of the border is presented on the Figure 4. Additionally, border towns are coloured darker to represent SSA border territories at extreme risk of conflict.

\subsection{Conclusion}

Borders in territorial analyses of conflict analysis have typically fallen into Agnew's (1994) "territorial trap." Specifically, borders are typically treated as legal boundaries that dichotomously delimit the domestic from the foreign. Analyses of borderlands, however, have described borders and border spaces with more nuance, complexity, and behavioural influence than is common in conflict analyses, especially in SSA. This paper attempts to bridge these disciplines by integrating principles of borderland studies into a disaggregated territorial analysis of rebel conflict capabilities in SSA.

Firstly, I position borderlands at the center of my study. Where similar location-based analyses of conflict focus on projection of government power that emanates from capital cities, I focus on the power projection sourced from, or across, the border. Secondly, my central hypothesis, that territory nearer to the border experiences more rebel conflict compared to other territories in the same country, presents a non-dichotomous effect of borders on nearby territory. The operationalization of this hypothesis with a continuous distance variable bakes the borders' gradated effect into the final estimation results. Thirdly, I disaggregate the length of the border to consider differentiated border effects on rebel capability. By hypothesizing and testing for the effects of border towns, lootable resources, rough terrain, and excluded groups at the border, this analysis forwards the concept of borders as complex and unique spaces, which require more nuanced attention rather than simplification.

In addition to the theoretical contribution of this interdisciplinary approach, the empirical results generally support this differentiated approach to a border's effect on the rebel conflict capabilities. The data structure permits a unit of analysis that is largely insensitive to geographic assumptions of the state as a homogeneously sovereign space and the results suggest that, indeed, borders exert a gradated influence on rebel capabilities. Ultimately, this supports the primary hypothesis that borders provide rebels with opportunities to access out-ofcountry resources and support. Additionally, the results suggest that border towns are at a significantly higher risk of rebel conflict compared to other territories within the country. The hypothesized causal link is that the unregulated cross-border institutions prevalent at many border towns in SSA can also facilitate material and personnel transfers in and out of the country. Rebels' exploitation of these cross-border links ultimately lends more capabilities to rebel operations in the area, permitting a greater projection of power. Notably, the results also suggest that neither resources, rough terrain, nor excluded groups at the border expressed a significant relationship with rebel conflict capability.

Despite the consistency of results, the empirical approach only presents correlational evidence for the relationship between border territories and rebel conflict counts and cannot fully evaluate the causal links that lead to these results. Further analysis is necessary to strengthen these results. Here, qualitative approaches can complement these findings. Specifically, the empirical results suggest that border towns, had a larger effect on rebel conflict capability compared to territories near de jure boundaries. Border towns are sites of complex cross-border and often self-regulating institutions. Further, variables related to geographic defensibility and conflict incentive at the border were not found to influence the risk of conflict one way or the other, suggesting a distinctiveness to the effect of border town institutions. While this analysis has presented evidence that supports a differentiated institutional effect of border towns on conflict risk, qualitatively identifying the causal channels on conflict risk within these border towns is hypothesized to be a fruitful avenue for further investigation. 
Ultimately, conflict analysis stands to significantly benefit from more disaggregated territorial studies of the border. Of the 14,120 rebel battle events in SSA from 1997-2019, about half (46.3\%) occurred within $50 \mathrm{~km}$ of an international border with a neighbouring country. Understanding this simplistic geographic observation can provide policy practitioners with additional contextual knowledge for reducing violent armed conflict in the region. The borderlands literature is well-placed for this task and conflict scholars have advantageous research tools at their disposal. Increased interdisciplinary collaborations between borderlands and conflict researchers in this regard, presents opportunities to build complementary research agendas and provide stronger frameworks for analysis of civil conflict hazards at the border.

\subsection{Annex. Resulting countries present in the data sample}

- Angola

- Benin

- Botswana

- Burkina Faso

- Burundi

- Cameroon

- Central African

Republic

- Chad

- Democratic Republic of

Congo

- Djibouti
- Côte d'Ivoire

- Equatorial
Guinea
- Eritrea
- Ethiopia
- Gabon
- Ghana
- Guinea
- Guinea-Bissau
- Kenya
- Lesotho
- Liberia
- Malawi
- Mali
- Mozambique

- Namibia

- Niger

- Nigeria

- Republic of Congo

- Rwanda

- Senegal

- Sierra Leone

- South Africa

- Tanzania

- Togo

- Uganda

- Zambia

- Zimbabwe

\section{Notes}

1 An example of international cooperation to fight cross border insurgencies is Nigerian-Cameroon cooperation against Boko Haram in Northern Nigeria.

2 The complete definition of rebels provided by Raleigh et al. (2010) to populate the dataset is:

Rebel groups are identified as political organizations designed to counter an established governing regime within a state through engaging in violent acts. Rebel groups have a stated political agenda, are acknowledged outside of immediate members, and use violence as the primary means to pursue political goals (655).

3 While population size is acknowledged to change over time, meaningful non-interpolated time-sensitive data is not available. While the GPWv4 dataset does provide data for 5-year periods, they explicitly acknowledge that the data does not reflect a true time series as the population estimates are derived from the same input population data and interpolated between years. Given that population growth rates are slow to change over decades, this variable still serves as a reasonable structural proxy for population size within the gridded cell.
4 Recent work has shown that testing for zero inflation using the standard Stata15 Vuong test may be inappropriate. To adjust for this, the Vuong test was performed with Akaike information criterion and Bayesian information criterion corrections. See Desmarais and Harden (2013) for more information.

5 The inflate equation could be considered a test of the gridded structure's performance, rather than relevant to corollary channels of conflict onset. The results suggest that the grid format is well suited to identifying conflict onset when considering the signs of the coefficients. For example, the inflate equation's results for all models suggest that more populous locations had a higher probability of seeing at least one war event (negative coefficients suggest the probability of observing a non-zero event). This may be an unsurprising attribute of the data structure: conflict is likely to occur where people are located. However, the effect of population on conflict is more robustly explored in Raleigh and Hegre's (2009) spatial analysis. Similarly, the inflate equation's results suggest that nearby rebel battles predicts a higher probability of seeing at least one war event in the reference cell. Again, this could be related to the spatial design of the grid structure: rebel battles occur near other rebel battles (the data indicates a $44 \%$ correlation). But, considering the spatial spillover theories described, this is also theoretically sound.

\section{Works Cited}

Aas Rustad, Siri Camilla, Halvard Buhaug, Åshild Falch, and Scott Gates. 2011. "All Conflict Is Local: Modeling Sub-National Variation in Civil Conflict Risk." Conflict Management and Peace Science 28 (1): 15-40. https:// doi.org/10.1177/0738894210388122

Acemoglu, Daron, and James A. Robinson. 2012. Why Nations Fail: The Origins of Power, Prosperity and Poverty. London: Profile Books.

Ackleson, Jason. 2003. "Directions in Border Security Research." The Social Science Journal, Focus on U.S.-Mexico Border Issues, 40 (4): 573-81. https://doi. org/10.1016/S0362-3319(03)00069-7.

Adepoju, Aderanti. 1984. "Illegals and Expulsion in Africa: The Nigerian Experience." International Migration Review 18 (3): 426-36. https://doi. org/10.2307/2545878.

Agnew, John. 1994. "The Territorial Trap: The Geographical Assumptions of International Relations Theory." Review of International Political Economy 1 (1): 53-80. https://doi.org/10.1080/09692299408434268.

Agnew, John, Katharyne Mitchell, and Gerard Toal. 2008. A Companion to Political Geography. John Wiley \& Sons.

Agnew, John, and Stuart Crobridge. 2002. Mastering Space: Hegemony, Territory and International Political Economy. Routledge.

Alusala, Nelson. 2010. "Informal Cross-Border Trade and Arms Smuggling along the Uganda-Rwanda Border." 
Borders in Globalization Review | Volume 1 | Issue 1 | Fall 2019

Hadley, "Borders and the Feasibility of Rebel Conflict"

African Security Review 19 (3): 15-26. https://doi.org/1 $0.1080 / 10246029.2010 .519875$.

Andersen, Dorte, Martin Klatt, and Marie Sandberg. 2012. The Border Multiple: The Practicing of Borders between Public Policy and Everyday Life in a Re-Scaling Europe. Edited by Dorte Jagetic Andersen, Martin Klatt, and Marie Sandberg. London: Routledge.

Andreas, Peter. 2003. "Redrawing the Line: Borders and Security in the Twenty-First Century." International Security 28 (2): 78-111. https://doi. org/10.1162/016228803322761973.

Ayissi, Anatole. 2009. "The Politics of Frozen State Borders in Postcolonial Africa." In African Studies in Geography from Below, edited by Michel Ben Arrous and Lazare Ki-Zerbo. Dakar, Senegal: African Books Collective.

Balestri, Sara. 2012. "Gold and Civil Conflict Intensity: Evidence from a Spatially Disaggregated Analysis." Peace Economics, Peace Science, and Public Policy 18 (3): 1-7.

Bigo, Didier. 2006. "Internal and External Aspects of Security." European Security 15 (4): 385-404. https:// doi.org/10.1080/09662830701305831.

Blake, Gerald. 2000. "State Limits in the Early Twenty-first Century: Observations on Form and Function." Geopolitics 5 (1): 1-18. https://doi. org/10.1080/14650040008407664.

Blyth, Simon, Brian Groombridge, Igor Lysenko, Lera Miles, and Adrian Newton. n.d. "Mountain Watch: Environmental Change \& Sustainable Development in Mountains - UNEP-WCMC." 12. Biodiversity Series. UNEP-WCMC. Accessed September 30, 2019. https:// portals.iucn.org/library/node/26639.

Boulding, Kenneth Ewart. 1962. Conflict and Defense: A General Theory. Harper.

Buhaug, Halvard. 2006. "Relative Capability and Rebel Objective in Civil War." Journal of Peace Research 43 (6): 691-708. https://doi.org/10.1177/0022343306069255.

_ . 2010. "Dude, Where's My Conflict? LSG, Relative Strength, and the Location of Civil War." Conflict Management and Peace Science 27 (2): 107-28. https:// doi.org/10.1177/0738894209343974.

Buhaug, Halvard, and Jan Ketil Rød. 2006. "Local Determinants of African Civil Wars, 1970-2001." Political Geography 25 (3): 399-418. https://doi.org/10.1016/j. polgeo.2006.02.005.

Buhaug, Halvard, and Kristian Skrede Gleditsch. 2008. "Contagion or Confusion? Why Conflicts Cluster in Space." International Studies Quarterly 52 (2): 215-33. https://doi.org/10.1111/j.1468-2478.2008.00499.x.

Buhaug, Halvard, and Päivi Lujala. 2005. "Accounting for Scale: Measuring Geography in Quantitative Studies of Civil War." Political Geography 24 (4): 399-418. https:// doi.org/10.1016/j.polgeo.2005.01.006.

Buhaug, Halvard, Scott Gates, and Päivi Lujala. 2009. "Geography, Rebel Capability, and the Duration of Civil Conflict." Journal of Conflict Resolution 53 (4): 544-69. https://doi.org/10.1177/0022002709336457.

Carment, David, and Albrecht Schnabel. 2004. Conflict Prevention from Rhetoric to Reality: Opportunities and Innovations. Volume 2. Lexington Books.

Center for International Earth Science Information Network
- CIESIN - Columbia University. 2016. "Gridded Population of the World, Version 4 (GPWv4): Population Count." Palisades, NY: NASA Socioeconomic Data and Applications Center (SEDAC).

Collier, Paul, and Anke Hoeffler. 2004. "Greed and Grievance in Civil War." Oxford Economic Papers 56 (4): 563-95. https://doi.org/10.1093/oep/gpf064.

Collier, Paul, Anke Hoeffler, and Dominic Rohner. 2009. "Beyond Greed and Grievance: Feasibility and Civil War." Oxford Economic Papers 61 (1): 1-27. https://doi. org/10.1093/oep/gpn029.

Côté-Boucher, Karine, Federica Infantino, and Mark B. Salter. 2014. "Border Security as Practice: An Agenda for Research." Security Dialogue 45 (3): 195-208. https://doi.org/10.1177/0967010614533243.

Davis, David R., and Will H. Moore. 1997. "Ethnicity Matters: Transnational Ethnic Alliances and Foreign Policy Behavior.” International Studies Quarterly 41 (1): 171-84.

Denny, Elaine K, and Barbara F Walter. 2014. "Ethnicity and Civil War." Journal of Peace Research 51 (2): 199-212.

Desmarais, Bruce A., and Jeffrey J. Harden. 2013. "Testing for Zero Inflation in Count Models: Bias Correction for the Vuong Test." The Stata Journal: Promoting Communications on Statistics and Stata 13 (4): 810-35. https://doi.org/10.1177/1536867X1301300408.

Diehl, Paul F. 1991. "Geography and War: A Review and Assessment of the Empirical Literature." International Interactions 17 (1): 11-27. https://doi. org/10.1080/03050629108434768.

Dietrich, Chris. 2000. "The Commercialisation of Military Deployment in Africa." African Security Review 9 (1): 3-17. https://doi.org/10.1080/10246029.2000.96280 32.

Duffield, Mark. 2001. Global Governance and the New Wars: The Merging of Development and Security. London: Zed Books Ltd.

Egg, Johny, and John Ogunsola Igué. 1993. "Market-Driven Integration in the Eastern Subregion. Nigeria's Impact on Its Immediate Neighbours: Summary Report."

Englebert, Pierre. 2002. State Legitimacy and Development in Africa. Lynne Rienner Publishers.

Forsberg, Erika. 2008. "Polarization and Ethnic Conflict in a Widened Strategic Setting." Journal of Peace Research 45 (2): 283-300.

Gilmore, Elisabeth, Nils Petter Gleditsch, Päivi Lujala, and Jan Ketil Rod. 2005. "Conflict Diamonds: A New Dataset." Conflict Management and Peace Science 22 (3): 257-72. https://doi.org/10.1080/07388940500201003.

Gleditsch, Kristian Skrede. 2009. All International Politics Is Local: The Diffusion of Conflict, Integration, and Democratization. University of Michigan Press.

Gleditsch, Nils Petter, Kathryn Furlong, Håvard Hegre, Bethany Lacina, and Taylor Owen. 2006. "Conflicts over Shared Rivers: Resource Scarcity or Fuzzy Boundaries?" Political Geography, Special Issue: Conflict and Cooperation over International Rivers, 25 (4): 361-82. https://doi.org/10.1016/j.polgeo.2006.02.004.

Griffiths, leuan. 2005. The African Inheritance. Routledge. . 1996. "Permeable Boundaries in Africa." In African Boundaries: Barriers, Conduits and Opportunities, edited by Paul Nugent and Asiwaju I. A. London: Pinter Publ. 
Gurr, Ted Robert. 1970. Why Men Rebel. Paradigm Publishers.

Hadley, Lance, and Mary Rowlatt. 2019. "Innovating Past Data Collection Obstacles for East Africa's Women Cross-Border Traders: Evidence from Sauti East Africa." presented at the Sustainable and Inclusive Trade (SIAT) Symposium: Women in Trade for Sustainable Development, Nairobi, Kenya, September. https:// doi.org/10.13140/RG.2.2.26944.69123.

Hashim, Yahaya, and Kate Meagher. 1999. Cross-Border Trade and the Parallel Currency Market: Trade and Finance in the Context of Structural Adjustment: A Case Study from Kano, Nigeria. Nordic Africa Institute.

Herbst, Jeffrey Ira. 2000. States and Power in Africa: Comparative Lessons in Authority and Control. Princeton Studies in International History and Politics. Princeton, N.J: Princeton University Press.

Humphreys, Macartan. 2005. "Natural Resources, Conflict, and Conflict Resolution: Uncovering the Mechanisms." Journal of Conflict Resolution 49 (4): 508-37. https:// doi.org/10.1177/0022002705277545.

Igué, Ogunsola John, and B. Soulé. 1992. L'Etat entrepôt au Bénin: Commerce informel ou solution à la crise? Paris: Karthala.

Jackson, Robert H. 1993. Quasi-States: Sovereignty, International Relations and the Third World. Cambridge University Press.

Jackson, Robert H., and Carl G. Rosberg. 1982. "Why Africa's Weak States Persist: The Empirical and the Juridical in Statehood." World Politics 35 (1): 1-24. https://doi.org/10.2307/2010277.

Klare, Michael. 2001. Resource Wars: The New Landscape of Global Conflict. Macmillan.

Konadu-Agyemang, Kwadwo. 2000. "The Best of Times and the Worst of Times: Structural Adjustment Programs and Uneven Development in Africa: The Case Of Ghana." The Professional Geographer 52 (3): 469-83. https://doi.org/10.1111/0033-0124.00239.

Korf, B., and T. Raeymaekers. 2013. Violence on the Margins: States, Conflict, and Borderlands. Springer.

Koroma, Suffyan, Joan Nimarkoh, You Ny, Victor Ogalo, and Boniface Owino. 2017. "Formalization of Informal Trade in Africa Trends, Experiences and Socio-Economic Impacts." Accra: Food and Agriculture Organization of the United Nations.

Kuran, Timur. 1987. "Preference Falsification, Policy Continuity and Collective Conservatism." The Economic Journal 97 (387): 642-65. https://doi. org/10.2307/2232928.

Le Billon, Philippe. 2014. Wars of Plunder: Conflicts, Profits and the Politics of Resources. Oxford University Press.

Lesser, Caroline, and Evdokia Mois-Leeman. 2009. "Informal Cross-Border Trade and Trade Facilitation Reform in Sub-Saharan Africa." OECD, Trade Directorate, OECD Trade Policy Working Papers, January.

Lidow, Nicholai Hart. 2016. Violent Order: Understanding Rebel Governance through Liberia's Civil War. Cambridge University Press.

Lindemann, Stefan. 2008. "Do Inclusive Elite Bargains Matter?" Discussion Paper 15. Crisis States Discussion Papers. London: Development Studies Institute London School of Economics and Political Science.
Lujala, Paivi. 2009. "Deadly Combat over Natural Resources: Gems, Petroleum, Drugs, and the Severity of Armed Civil Conflict." Journal of Conflict Resolution 53 (1): 50-71. https://doi.org/10.1177/0022002708327644.

Meagher, Kate. 2001. "Throwing Out the Baby to Keep the Bathwater: Informal Cross-Border Trade and Regional Integration in West Africa." In Regionalism and Regional Integration in Africa: A Debate of Current Aspects and Issues. Nordic Africa Institute.

_ 2003. "A Back Door to Globalisation? Structural Adjustment, Globalisation \& Transborder Trade in West Africa." Review of African Political Economy 30 (95): 57-75. https://doi.org/10.1080/03056240308374.

Meiyappan, Prasanth, and Atul K. Jain. 2012. "Three Distinct Global Estimates of Historical Land-Cover Change and Land-Use Conversions for over 200 Years." Frontiers of Earth Science 6 (2): 122-39. https://doi.org/10.1007/ s11707-012-0314-2.

Ministry of Trade and Industry - Rwanda. 2013. "National Cross-Border Trade Strategy 2012-2017." Kigali: Ministry of Trade and Industry.

Mkandawire, Thandika. 2001. "Thinking about Development States in Africa." Cambridge Journal of Economics 25 (3): 289-313.

Murdoch, J. C. and Sandler, T. 2004. "Civil Wars and Economic Growth: Spatial Dispersion" American Journal of Political Science 48 (1): 138-151. https:// doi:10.1111/j.0092-5853.2004.00061.x

Muzvidziwa, Victor N. 2005. Women without Borders: Informal Cross-Border Trade among Women in the Southern African Development Community. http:// ir.msu.ac.zw:8080/xmlui/handle/11408/936.

Newman, David. 2008. "Boundaries." In A Companion to Political Geography, edited by John A. Agnew, Katharyne Mitchell, and Gerard Toal. Massachusetts: Blackwell Publishing Ltd.

- 2006a. "Borders and Bordering: Towards an Interdisciplinary Dialogue." European Journal of Social Theory 9 (2): 171-86. https://doi. org/10.1177/1368431006063331.

_. 2006b. "The Lines That Continue to Separate Us: Borders in Our 'borderless' World." Progress in Human Geography 30 (2): 143-61. https://doi. org/10.1191/0309132506ph599xx.

Niang, Amy. 2013. "The (In)Commodities of Laissez-Faire Integration: Trade and Mobility in a Cross-Border Market." African Studies 72 (1): 41-63.

Nshimbi, Christopher Changwe, and Inocent Moyo. 2017. Migration, Cross-Border Trade and Development in Africa: Exploring the Role of Non-State Actors in the SADC Region. Springer.

Nugent, Paul, and A. I. Asiwaju. 1996. African Boundaries: Barriers, Conduits and Opportunities. London: Pinter Publ.

Paasi, Anssi. 2011. “A 'Border Theory': An Unattainable Dream or a Realistic Aim for Border Scholars?" In The Ashgate Research Companion to Border Studies, 11-31.

Parker, Noel, and Nick Vaughan-Williams et al. 2009. "Lines in the Sand? Towards an Agenda for Critical Border Studies." Geopolitics 14 (3): 582-87. https://doi. org/10.1080/14650040903081297. 
Borders in Globalization Review | Volume 1 | Issue 1 | Fall 2019

Hadley, "Borders and the Feasibility of Rebel Conflict"

Peberdy, Sally Ann. 2000. "Border Crossings: Small Enterpreneurs and Cross-Border Trade between South Africa and Mozambique." Tijdschrift Voor Economische En Sociale Geografie 91 (4): 361-78. https://doi. org/10.1111/1467-9663.00124.

Raleigh, Clionadh, and Håvard Hegre. 2009. "Population Size, Concentration, and Civil War. A Geographically Disaggregated Analysis." Political Geography 28 (4): 224-38. https://doi.org/10.1016/j.polgeo.2009.05.007.

Raleigh, Clionadh, Andrew Linke, Håvard Hegre, and Joakim Karlsen. 2010. "Introducing ACLED: An Armed Conflict Location and Event Dataset: Special Data Feature." Journal of Peace Research 47 (5): 651-60. https://doi.org/10.1177/0022343310378914.

Reid-Henry, Simon. 2010. "The Territorial Trap Fifteen Years On.” Geopolitics 15 (4): 752-56. https://doi. org/10.1080/14650041003717509.

Ruggeri, Andrea, Han Dorussen, and Theodora-Ismene Gizelis. 2017. "Winning the Peace Locally: UN Peacekeeping and Local Conflict." International Organization 71 (1): 163-85. https://doi.org/10.1017/ s0020818316000333.

Rustad, Siri Camilla Aas, Jan Ketil Rød, Wenche Larsen, and Nils Petter Gleditsch. 2008. "Foliage and Fighting: Forest Resources and the Onset, Duration, and Location of Civil War." Political Geography 27 (7): 761-82. https://doi.org/10.1016/j.polgeo.2008.09.004.

Saideman, Stephen M. 1997. "Explaining the International Relations of Secessionist Conflicts: Vulnerability versus Ethnic Ties." International Organization 51 (4): 721-53.

- 2002. "Discrimination in International Relations: Analyzing External Support for Ethnic Groups." Journal of Peace Research 39 (1): 27-50. https://doi.org/10.1177 /0022343302039001002.

Salehyan, Idean. 2008. "The Externalities of Civil Strife: Refugees as a Source of International Conflict." American Journal of Political Science 52 (October): 787-801. https://doi.org/10.1111/j.15405907.2008.00343.x.

Schroeder, Matt, and Guy Lamb. 2006. "The Illicit Arms Trade in Africa: A Global Enterprise." African Analyst 3 (1): 69-78.

Söderbaum, Fredrik. 2016. "The Role of the Regional Factor in West Africa." In The New Regionalism and the Future of Security and Development, edited by Björn Hettne, Andras Inotai, and Osvolda Sunkel. Springer.

Sohn, Christophe. 2014. "Modelling Cross-Border Integration: The Role of Borders as a Resource." Geopolitics 19 (3): 587-608. https://doi.org/10.1080/14650045.2014.913029.

Southern African Development Community. 2010. "Advocacy
Strategy on Informal Cross Border Trade." Harare, Zimbabwe: Southern African Development Community.

Starr, Harvey, and G. Dale Thomas. 2005. "The Nature of Borders and International Conflict: Revisiting Hypotheses on Territory." International Studies Quarterly 49 (1): 123-39.

The World Bank. 2011. "Facilitating Cross-Border Trade between the DRC and Neighbors in the Great Lakes Region of Africa : Improving Conditions for Poor Traders."

Turner, Thomas. 2007. The Congo Wars: Conflict, Myth and Reality. New York: Zed Books.

Uchida, Hirotsugu, and Andrew Nelson. 2010. "Agglomeration Index Towards a New Measure of Urban Concentration." O29. WIDER Working Paper Series. World Institute for Development Economic Research (UNU-WIDER). https://ideas.repec.org/p/unu/wpaper/ wp2010-29.html.

Vasquez, John A. 1995. "Why Do Neighbors Fight? Proximity, Interaction, or Territoriality." Journal of Peace Research 32 (3): 277-93. https://doi.org/10.1177/0022 343395032003003.

Vogt, Manuel, Nils-Christian Bormann, Seraina Rüegger, Lars-Erik Cederman, Philipp Hunziker, and Luc Girardin. 2015. "Integrating Data on Ethnicity, Geography, and Conflict: The Ethnic Power Relations Data Set Family." Journal of Conflict Resolution 59 (7): 1327-42. https:// doi.org/10.1177/0022002715591215.

Walther, Olivier. 2011. "Integration of Informal Economic Cross-Border Networks in West Africa." West African Futures. OECD Paris: Centre for Population, Poverty and Public Policy Studies Luxembourg. https://www. oecd.org/swac/events/49008874.pdf.

Ward, Michael D., and Kristian Skrede Gleditsch. 2002. "Location, Location, Location: An MCMC Approach to Modeling the Spatial Context of War and Peace." Political Analysis 10 (3): 244-60. https://doi.org/10.1093/ pan/10.3.244.

Weidmann, Nils B. 2015. "Communication Networks and the Transnational Spread of Ethnic Conflict." Journal of Peace Research 52 (3): 285-96. https://doi. org/10.1177/0022343314554670.

Weidmann, Nils B., Doreen Kuse, and Kristian Skrede Gleditsch. 2010. "The Geography of the International System: The CShapes Dataset." International Interactions 36 (1): 86-106. https://doi.org/10.1080/03050620903554614.

Wilson, Thomas M., and Hastings Donnan. 1998. Border Identities: Nation and State at International Frontiers. Cambridge University Press.

Zureik, Elia, and Mark Salter. 2013. Global Surveillance and Policing. Routledge. 